\title{
A Study on the Effect of Job Stress on the Employees Performance in Crux Technologies Private Limited, Chennai
}

\author{
Dr. A. Ramasethu \\ Assistant Professor, Department of Commerce, Rathinam College of Arts and Science, Coimbatore
}

\begin{abstract}
Stress is non-specific response to demands from environment that results in physical, psychological and/or behavioral deviations for people. No one is immune to stress. Stress in work settings stems from different sources such as individuals, group, organizational and environmental. It is better to bend than to break. Hence the need for coping with Stress. This study was done on Job Stress On The Employees Performance In Crux Technologies Private Limited, Chennai. Company wants to know the organizational stress in the company. Stress may occur to employees due to several factors (i.e.) both Internal and External. Internal Factor that creates stress to workers should be avoided. Internal factors create Job dissatisfaction and may result in absenteeism and turnover. So company wants to know about the employees feeling and opinion of the employees to overcome Stress. The objective of the study is to know the causes and effects of Stress and also to find out the best method to overcome Stress. The data was collected by interviewing directly the employees and not the Managers. Convenience sampling method was used for this study. The sample size was 160. Both primary and secondary sources of data were extensively used by analyzing this study. It was found that $82 \%$ of the Respondents are affected due to stress, Majority of the respondents were responded that personal reasons, changes in organization, Family demands and obligation, fear of achieving target, difficulty in concentrating in their work are the causes and effects of Stress. They suggested in improving the working condition in order to overcome Stress.
\end{abstract}

\section{Operational Definition}

\section{Introduction}

Stress is the general term applied to the pressure, people feel in life. The presence of stress at work is almost inevitable in most of jobs. However individual differences accounts for a wide range of reaction to stress. A task viewed as challenging by one person may produce high levels of anxiety in another. When person's emotions, employees develop various symptoms of stress that can harm their job performance and health, and even threaten their ability to cope with the environment. Stress also leads to physical disorder, because the internal body system changes to try to cope with stress. Stress leads to family problems. When Stress over prolonged it also leads to degenerative diseases of heart, kidney, blood pressure and parts of body.

\section{Causes Of Stress \\ Environmental Factors}

Just as environmental influences the design of an organization Technology uncertainty is type of environmental factor that can causes stress because new innovations can make an employee's skills and experience obsolete in a very short period of fire, robotics automation threat to employee. The various environmental factors used for this study are:

- Fast technological change

- Family demands and obligation

- Economic and financial Conditions

- Relocation

- Ethnic identity

\section{Organizational Factors}

There are no shortages of factors within the organization that can cause stress. Pressure to avoid errors or complete tasks in a limited time period, work overload. The various Organizational factors used for this study are:

- Unfair Performance evaluation

- Inequality in remuneration \& incentives

- Leadership style

- fear of achieving target

- Pressure from superior 


\subsection{Statement Of The Problem:}

$>$ Crux Technologies (P) Limited, one of the growing human resources outsourcing company office situated in Chennai. The research is done among the employees working in the office.

$>$ This research deals with the effect of stress on the employee's performance. This study also deals with various other problems like causes of stress, effect of stress, relationship with superiors and co-workers. The importance of this study is to formulate control measures to overcome employees stress.

\subsection{Scope Of The Study}

The scope of the study is to find out the effect of stress on employees performance and it does not cover manager's performance. This study covers only employees in Chennai. The researcher has chosen 100 respondents for this study.

\subsection{Objectives Of The Study}

$>$ To find out the causes of stress.

$>$ To identify the effect of stress.

$>$ To find out the techniques to overcome stress

\subsection{Review Of Literature On Job Stress}

1. According to Terry A. Beehr and john John E. Newman the empirical research that has been done is reviewed within the context of six facets (i.e., environmental, personal, process, human consequences, organizational consequences, and time) of seven facet conceptualization of the job stress-employee health research domain. A general and a sequential model are proposed for tying the facets together. It was concluded by them that the major problems of the research in this area are: confusion in the use of terminology regarding the elements of job stress, relatively weak methodology within specific studies, the lack of systematic approaches, and the lack of attention to many elements of the specific facets.

2. The main aim of the research work done by Sharon Glazer, Terry A. Beehr is relationship between role stressors, anxiety, commitment and turnover intention. Three role stressors were expected to predict anxiety and indirectly predict intention to leave. Anxiety was expected to predict affective and continuance commitment, and anxiety, affective commitment, and continuance commitment, were expected to predict intention to leave the hospital. Although mean score differences were expected across countries, direction of the relationships between variables were expected to be the same, which would indicate consistency regarding the implications of three role stressors across countries.

It was tentatively concluded that stress us a culture-general process.

3. Dr. Michael J. Kavanagh has examined the workplace as a source of potential stressors. Job satisfaction was measured with self-report instruments while psychiatric symptomatology was assessed via a standardized diagnostic interview. The results provide strong support for the existence of the hypothesized relationship. Satisfaction with the work itself for ATCs, followed closely by coworker satisfaction, showed the most frequent relationships to the presence or absence of different psychiatric symptoms. The results are discussed in terms of their relationship to research on related stress.

4. Research work done by Rebecca Abraham describes the moderation of role stress, specified by role ambiguity, conflict and overload, and job satisfaction by thinking styles. Principal findings included the moderation of the role ambiguity-job satisfaction relationship by the global style; the role overload-job satisfaction relationship by the hierarchic style and the judicial style acting jointly with task significance.

\section{Research Design}

\section{Research Methodology}

"A Research Design is the arrangement of conditions for the collection and analysis of data in a manner that aims to combine relevance of the research purpose with economy in procedure".

The Research Design used for this study is "Descriptive research" whose purpose is to describe accurately the characteristics of a particular individual, or of a group.

\section{Sources Of Data}

\section{Data Collection}

The data are collected, both from primary sources and also from secondary sources. 


\section{Tools For Data Collection}

The tool which is used for collecting primary data is structured questionnaire whereas secondary data are to be collected through Books, Magazines, Newspaper, Journals, and Electronic sources and from the organization.

\section{Data Collection Method}

The primary data is collected through questionnaires.

\section{Sample Size}

Population of the study is 160 employees.

The sample size taken is 100 employees.

\section{Samling Method}

The sampling method adopted for this study is "Convenience Sampling".

\section{Research Tool}

Tools used for the research is Percentage Analysis and Chi-square test.

\subsection{Limitations}

- It was difficult to access with employees.

- Due to the lack of response, the size is restricted to 100.

- It is possible that some of the respondents might have perceived that the study is being backed by the management and this might have affected the reliability of their response.

\subsection{Analysis And Interpretation}

These information are collected from 100 respondents are analyzed and interpreted by using percentage method and Chi-square analysis

\section{Table 1.1: Gender Of The Respondents}

\begin{tabular}{|c|c|c|}
\hline ATTRIBUTES & NO. OF RESPONDENTS & \% \\
\hline Male & 34 & 34 \\
\hline Female & 66 & 66 \\
\hline TOTAL & $\mathbf{1 0 0}$ & $\mathbf{1 0 0}$ \\
\hline
\end{tabular}

(Source: Primary Data)

\section{Interpretation:}

It is observed from the above table that out of 100 Respondents $66 \%$ of the Respondents are female and the remaining $34 \%$ of the Respondents are female.

Figure 1.1

\section{Gender Of The Respondents}

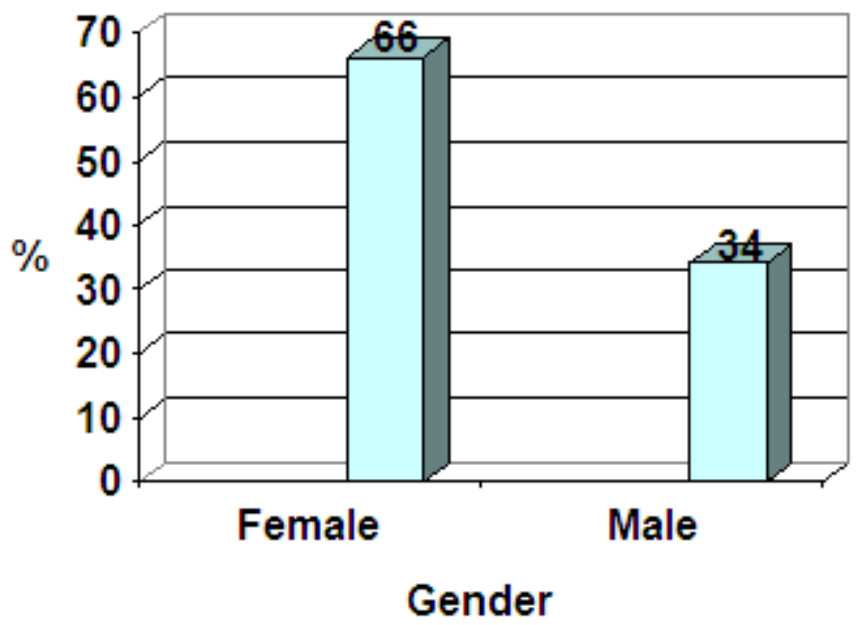


Table 1.2: Age Of The Respondents

(Source: Primary Data)

\begin{tabular}{|c|c|c|}
\hline ATTRIBUTES & NO. OF RESPONDENTS & \% \\
\hline Below 20 years & 13 & 58 \\
\hline 21 to 30 years & 58 & 27 \\
\hline 31 to 40 years & 27 & - \\
\hline 41 to 50 years & - & - \\
\hline Above 51 & - & $\mathbf{1 0 0}$ \\
\hline TOTAL & $\mathbf{1 0 0}$ & \\
\hline
\end{tabular}

\section{Interpretation}

The above table clearly reveals the age group of the Respondents in the study area. $58 \%$ of the Respondents belong to the age category of 21 to 30 years, $27 \%$ of Respondents belongs to the age category of 31 to 40 years and the remaining $13 \%$ of Respondents belongs to the age group of below 20 years.

\section{Figure 1.2}

\section{Age Of The Respondents}

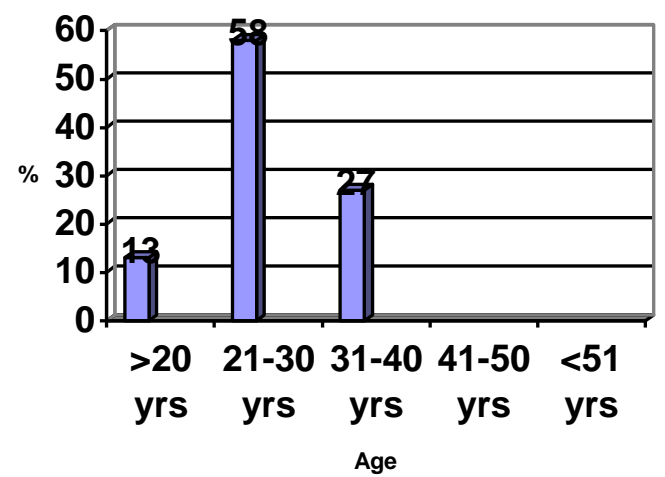

Table 1.3: Educational Qualification Of The Respondents

\begin{tabular}{|c|c|c|}
\hline ATTRIBUTES & NO. OF RESPONDENTS & \% \\
\hline U.G & 37 & 47 \\
\hline P.G & 46 & 17 \\
\hline Diploma Courses & 17 & $\mathbf{1 0 0}$ \\
\hline TOTAL & $\mathbf{1 0 0}$ & \\
\hline
\end{tabular}

(Source: Primary Data)

\section{Interpretation:}

The above table evidence that, a majority of $46 \%$ of the Respondents are Post graduate, $37 \%$ of the Respondents are under graduate and the remaining $17 \%$ of the Respondents are Diploma holder.

Figure 1.3

Educational Qualification

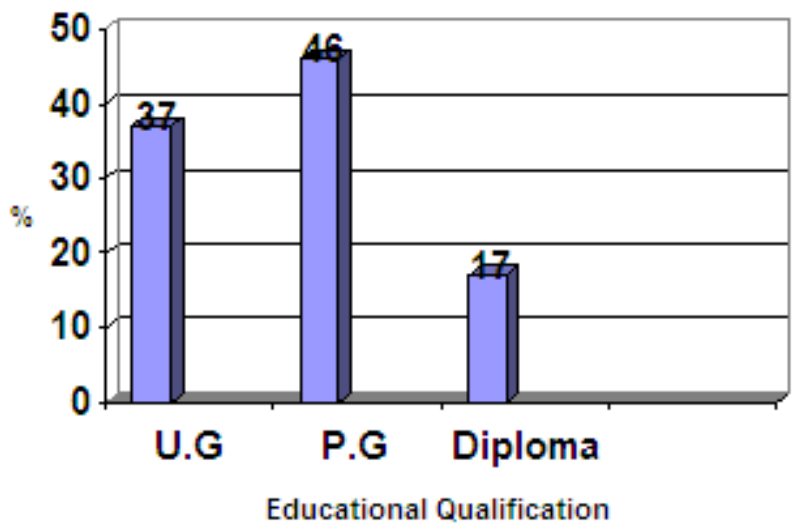


Table 1.4: Marital Status Of The Respondents

(Source: Primary Data)

\begin{tabular}{|c|c|c|}
\hline ATTRIBUTES & NO. OF RESPONDENTS & \% \\
\hline Married & 31 & 31 \\
\hline Unmarried & 69 & 69 \\
\hline TOTAL & $\mathbf{1 0 0}$ & $\mathbf{1 0 0}$ \\
\hline
\end{tabular}

\section{Interpretation:}

It is observed from the above table that out of 100 Respondents interviewed for the study majorities of $69 \%$ of the Respondents are Unmarried and the remaining $31 \%$ of Respondents are married.

Figure 1.4

\section{Marital Status}

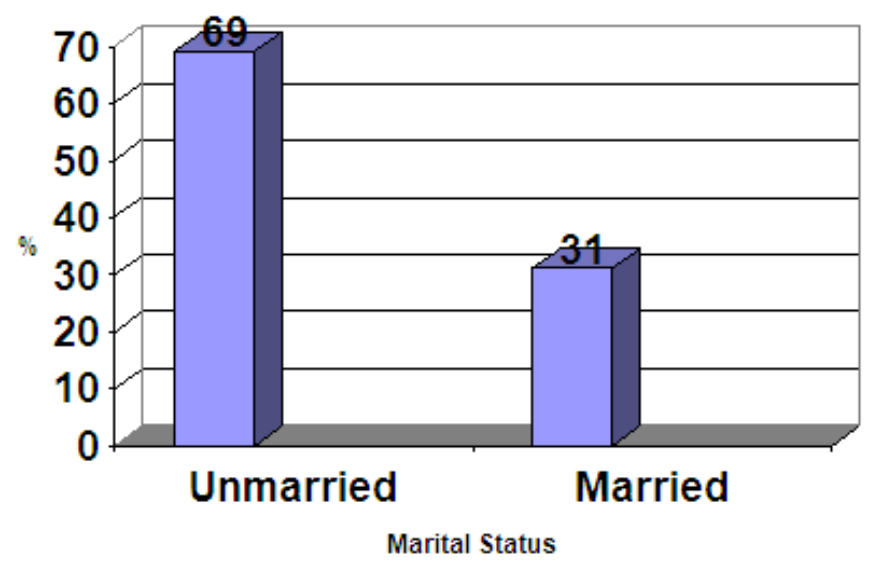

Table 1.5: Classification On The Basis Of Monthly Income

\begin{tabular}{|c|c|c|}
\hline \multicolumn{1}{|c|}{ ATTRIBUTES } & NO. OF RESPONDENTS & \% \\
\hline Below Rs.5,000 & 9 & 60 \\
\hline Rs. 5,001- 10,000 & 60 & 24 \\
\hline Rs.10,001- 15,000 & 24 & 7 \\
\hline above Rs.15,000 & 7 & $\mathbf{1 0 0}$ \\
\hline
\end{tabular}

(Source: Primary Data)

\section{Interpretation:}

It is vivid from the above table that a majority of $60 \%$ of the Respondents are earning a monthly income of Rs. 5,001- 10,000, 24\% of the Respondents are earning a monthly income of Below Rs.10, 000-Rs. 15,000, 9\% of the Respondents are earning a monthly income of below Rs. 5000/- and the remaining 7\% of the Respondents are earning a monthly income of Rs. 15,000 and above.

Figure 1.5

\section{Salary Drawn}

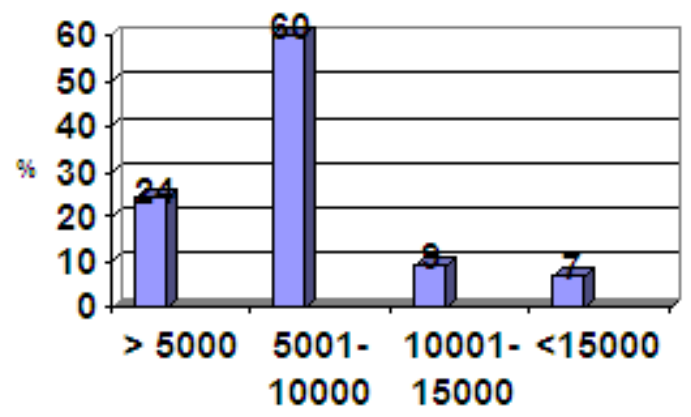

Salary 
Table 1.6

\begin{tabular}{|c|c|c|}
\hline ATTRIBUTES & NO. OF RESPONDENTS & $\%$ \\
\hline Job security & 12 & $\mathbf{1 2}$ \\
\hline Good working condition & 32 & 10 \\
\hline Adequate training & 10 & 30 \\
\hline Lighter work load & 30 & 16 \\
\hline Increase in pay & 16 & 100 \\
\hline TOTAL & 100 & 10 \\
\hline
\end{tabular}

(Source: Primary Data)

\section{Interpretation:}

It is significant to note that majorities of each $32 \%$ of the Respondents expect good working condition, $30 \%$ of them expect the company to give lighter work load, $16 \%$ of them expect increase in pay, $12 \%, 10 \%$ of them expect job security and adequate training from the company to manage stress.

Figure 1.6: Suggestions To Overcome Stress

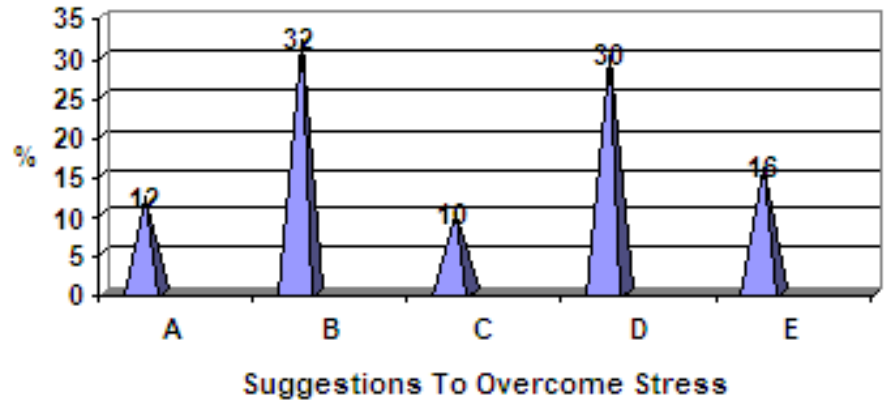

A = Job security, $B$ = Good working condition, $C=$ Adequate training, $\mathrm{D}=$ Lighter workload, $\mathrm{E}=$ Increase in pay

\section{Chi-Square Analysis}

The Chi square $\square$ test is one of the simplest and most widely used Non- Para-metric tests in statistical work. It makes no assumptions about the population being sampled. The quantity Chi square describes the magnitude of discrepancy between theory and observation, i.e., with the help of Chi square $\square$ test we can know whether a given discrepancy between theory observation can be attributed to chance or whether it results from the inadequacy of the theory to fit the observed facts.

Test the significance relationship between Service of employees and Measures of Relaxation .Test the result with the help of Chi-square at $5 \%$ level of significance.

$H_{0}=$ There is no significance relationship between Service of employees and Measures of Relaxation.

$\mathbf{H}_{1}=$ There is significance relationship between Service of employees and Measures of Relaxation.

Take the hypothesis that there is no significance relationship between Service of employees and Measures of Relaxation.

$S$ - Sleep

W - Go for Walk

M - Listen to Music

F - Sharing with Friends

O - Others

Table 1.7: Relationship Between Service of employees and Measures of Relaxation.

Observed Frequency

\begin{tabular}{|c|c|c|c|c|c|}
\hline \multirow{2}{*}{$\begin{array}{c}\text { SERVICE } \\
\text { OF EMPLOYEES }\end{array}$} & \multicolumn{5}{|c|}{ MEASURES OF RELAXATION } \\
\cline { 2 - 6 } (in yrs) & $\mathrm{S}$ & $\mathrm{W}$ & $\mathrm{M}$ & $\mathrm{F}$ & $\mathrm{O}$ \\
\hline Below 1 & 4 & 6 & 9 & 29 & 3 \\
\hline $1-2$ & 3 & 3 & 4 & 12 & 2 \\
\hline $2-3$ & 1 & 2 & 2 & 8 & 1 \\
\hline Above 3 & 1 & 1 & 1 & 7 & 1 \\
\hline
\end{tabular}

(Source: Primary Data) 
Expected Frequency =

Row total $*$ Column total

Grand total

\section{Expected Frequency}

\begin{tabular}{|c|c|c|c|c|c|}
\hline \multirow{2}{*}{$\begin{array}{c}\text { SERVICE OF } \\
\text { EMPLOYEES } \\
\text { (in yrs) }\end{array}$} & \multicolumn{5}{|c|}{$\begin{array}{c}\text { MEASURES OF RELAXATION } \\
\text { (NO OF EMPLOYEES) }\end{array}$} \\
\cline { 2 - 6 } & $\mathrm{S}$ & $\mathrm{W}$ & $\mathrm{M}$ & $\mathrm{F}$ & $\mathrm{O}$ \\
\hline Below 1 & 4.59 & 6.12 & 8.16 & 28.56 & 3.57 \\
\hline $1-2$ & 2.16 & 2.82 & 3.84 & 13.44 & 1.68 \\
\hline $2-3$ & 1.26 & 1.68 & 2.24 & 7.84 & 0.98 \\
\hline Above 3 & 0.99 & 1.32 & 1.76 & 6.16 & 0.77 \\
\hline
\end{tabular}

(Source: Primary Data)

Formula:

$$
\text { Chi-square }=\frac{\sum(\mathbf{O}-\mathbf{E})^{2}}{\mathbf{E}}
$$

Degree of freedom (r-1) (c-1)

$=12$

$5 \%$ Level of significance is

$=0.05$

Calculated value Chi-square is

$=1.573$

Tabulated Value Chi-square is

$=21.026$

Calculated value is < Tabulated Value

$=$ Accepted

Calculated value is $>$ Tabulated Value

$=$ Not accepted

\section{Result:}

The calculated value of chi-square is 1.573 which is less then Tabulated value of chi-square 21.026.

Therefore,

$$
\mathrm{H}_{0} \text { is accepted. }
$$

(ie). There is no significance relationship between Service of employees and Measures of Relaxation.

\section{Table 1.8}

Relationship Between Service of Employees and Symptoms of Stress.

Test the significance relationship between Service of Employees and Symptoms of Stress. Test the result with the help of Chi-square at $5 \%$ level of significance.

\section{$\mathbf{H}_{0}=$ There is no significance relationship between Service of Employees and Symptoms of Stress. \\ $\mathrm{H}_{1}=$ There is significance relationship between Service of Employees and Symptoms of Stress.}

Take the hypothesis that there is no significance relationship between Service of Employees and Symptoms of Stress.

IR - Inability to Relax

$\mathrm{H}$ - Headache

W - Chronic Worry

$\mathrm{T}-$ Nervous \&Tensions

UA - Uncooperative Attitude

SP - Sleeping Problem

A - Absenteeism 
A Study on the Effect of Job Stress on the Employees Performance in Crux Technologies ....

\begin{tabular}{|c|c|c|c|c|c|c|c|}
\multicolumn{9}{c|}{ Observed Frequency } \\
\hline $\begin{array}{c}\text { SERVICE OF } \\
\text { EMPLOYEES } \\
\text { (in yrs) }\end{array}$ & \multicolumn{7}{|c|}{$\begin{array}{c}\text { SYMPTOMS OF STRESS } \\
\text { (NO OF EMPLOYEES) }\end{array}$} \\
\cline { 2 - 9 } & IR & H & W & T & UA & SP & A \\
\hline Below 1 & 7 & 21 & 3 & 4 & - & 7 & 9 \\
\hline $1-2$ & 3 & 8 & 2 & 1 & - & 4 & 6 \\
\hline $2-3$ & 1 & 5 & 1 & 2 & - & 2 & 3 \\
\hline Above 3 & 1 & 2 & 2 & 1 & - & 3 & 2 \\
\hline
\end{tabular}

(Source: Primary Data)

Expected Frequency $=$

Row total * Column total

Grand total

Expected Frequency

\begin{tabular}{|c|c|c|c|c|c|c|c|}
\hline \multirow{2}{*}{$\begin{array}{c}\text { SERVICE OF } \\
\text { EMPLOYEES } \\
\text { (in yrs) }\end{array}$} & \multicolumn{7}{|c|}{$\begin{array}{c}\text { SYMPTOMS OF STRESS } \\
\text { (NO OF EMPLOYEES) }\end{array}$} \\
\cline { 2 - 8 } & IR & H & W & T & UA & SP & A \\
\hline Below 1 & 6.12 & 18.36 & 4.08 & 4.08 & - & 8.16 & 10.2 \\
\hline $1-2$ & 2.88 & 8.64 & 1.92 & 1.92 & - & 3.84 & 4.8 \\
\hline $2-3$ & 1.68 & 5.04 & 1.12 & 1.12 & - & 2.24 & 2.8 \\
\hline Above 3 & 1.32 & 3.96 & 0.88 & 0.88 & - & 1.76 & 2.2 \\
\hline
\end{tabular}

(Source: Primary Data)

Formula:

$$
\text { Chi-square }=\frac{\sum(\mathbf{O}-\mathbf{E})^{2}}{\mathbf{E}}
$$

Degree of freedom (r-1) (c-1)

$$
=18
$$

$5 \%$ Level of significance is

$$
=0.05
$$

Calculated value Chi-square is

$$
=6.334
$$

Tabulated Value Chi-square is

$$
=28.86
$$

Calculated value is < Tabulated Value

= Accepted

Calculated value is $>$ Tabulated Value

$=$ Not accepted

\section{Result:}

The calculated value of chi-square is 28.86 which is less then Tabulated value of chi-square 6.334 .

Therefore,

$$
\mathrm{H}_{0} \text { is accepted. }
$$

There is no significance relationship between Service of Employees and Symptoms of Stress.

Following factors are found under this study:

\section{Findings Of The Study}

* $66 \%$ of the Respondents are female.

* $58 \%$ of the Respondents belong to the category of 21 to 30 years.

* $46 \%$ of the Respondents are Post graduate.

* 69\% of Respondents are Unmarried.

* $60 \%$ of the Respondents are earning a monthly income of Rs. 5,001- Rs.10,000/-.

- 51\% of the Respondents have experience of below 1 year.

* $17 \%$ of the Responses were that meaning of stress is pressure.

* $82 \%$ of the Respondents are affected due to stress.

* $36 \%$ of the Respondents feel that they are sometimes under pressure.

* $40 \%$ of the Respondents responded that personal reasons causes stress.

* $32 \%$ of respondents feel that the rotation of shift never causes stress. 
* $82 \%$ of the respondents feel that changes in organization causes stress to individuals.

* $65 \%$ of the Respondents responded that always they have difficulty in concentrating in their work.

* $46 \%$ of the Respondents say that fear of achieving target causes stress.

* $78 \%$ of the respondents responded that environmental factors cause stress.

* $40 \%$ of the Respondents say always environmental factors have impact on Stress.

* $65 \%$ of the Respondents say that Family demands and obligation causes stress.

* $46 \%$ of the Respondents Strongly Agree with the statement "Psychological problem caused due to low performance".

* $40 \%$ of the Respondents feel that stress can produce better performance rarely.

* $78 \%$ of the Respondents reveal that stress affects the performance.

* $40 \%$ of the Respondents say stress has high impact on performance.

* $48 \%$ of the Respondents say that complexity of the task affects stress on performance.

* $68 \%$ of the Respondents feel that they get along with their co-workers.

* $64 \%$ of the Respondents reveal that they get along with their co-workers always.

* 52\% of the Respondents feel that stress always affect the relationship between management and employees.

* $32 \%$ of the Respondents feel that competitive pressure with co-workers causes stress rarely.

* $56 \%$ of the Respondents share with friends to relax them from stress.

* $42 \%$ of the Respondents say that company takes the employees to tour in order to overcome stress.

* $32 \%$ of the Respondents expect good working condition.

Chi-square Test was conducted for the following criteria.

\begin{tabular}{|c|l|c|}
\hline S.No & \multicolumn{1}{|c|}{ Table } & Status \\
\hline 1 & Relationship between Service of Employees and Measures of Relaxation. & No Relationship. \\
\hline 2 & Relationship between Service of Employees and Symptoms of Stress. & No Relationship. \\
\hline
\end{tabular}

(Source: Primary Data)

\section{Recommendations And Suggestions}

Based on the findings and conclusions these are the recommendations and suggestions made:

\$ Social interaction with co-workers helps to reduce the stress at job.

* Employees should follow certain strategies like time management, physical exercise, relaxation training (yoga) and social support.

* Friendly talk and healthy conditions help people to reduce their family tension; it leads to reduce stress when employee enters into the work place.

* Exchange of ideas and sharing feelings between two persons reduce stress.

* Good listening confident building is the tools used for managing the stress.

* To reduce the competitive pressure, the management should conduct seminars, restrooms, audiotapes and providing permission for using any other recreation program.

\section{Conclusion}

The discussion made in this study proves that the stress on employees affect the production and other activities thus giving them enough training and giving information about stress will help them.

Stress is the important factor that leads to cause psychological and physiological problems. Performance will decline people experience illness, brought on by very intensive stress and react to high stress through absenteeism turnover, errors, dissatisfaction and reduced performance.

With reference to satisfaction, it may have some positive impact on job satisfaction which may be entered through performance. But most of the time, stress makes negative impact on satisfaction.

\section{Bibliography}

[1]. C.R.KOTHARI, RESEARCH METHODOLOGY, $10^{\text {th }}$ Edition, Vishwa Prakasham.

[2]. FRED LUTHANS, ORGANISATIONAL BEHAVIOUR, $9^{\text {th }}$ Edition, McGraw hill Higher Education Inc, 2002

[3]. STEPHEN P. ROBBINS, ORGANISATIONAL BEHAVIOUR, $9^{\text {th }}$ Edition, Pearson Education Inc, 2002

[4]. K. ASWATHAPPA, ORGANISATION BEHAVIOUR, millennium edition, Himalaya Publishing House, 2001

[5]. M.N. MISHRA, ORGANISATIONAL BEHAVIOUR, $9^{\text {th }}$ EDITION, Vikas Publications, 2002

[6]. S.S.KHANKA, ORGANISATIONAL BEHAVIOUR, $5^{\text {th }}$ EDITION, S.Chand Publications, 2006

[7]. WWW.Google.com 